\title{
Featured Commentary
}

\section{What You, Readers of AlB Insights, Said: Responses to the Article "Is Your 'IB' Research Truly "International'??"}

\author{
Jean J. Boddewyn, Baruch College, City University of New York, USA
}

In his article "Is Your 'IB' Research Truly International'?" (published in Volume 16, Issue 2, pages 3-5), Jean Boddewyn invited comments and questions from readers of AIB Insights. Professor Boddewyn received several of them, which he summarizes here, with some further comments.

\section{Management consultant and entrepreneur Brent}

Marcus, of CPI Interactive, agreed with Graham Astley's argument that "truly international" research requires identifying those unique characteristics of a nation-state, which provide it with a competitive advantage vis-à-vis another country. He claimed that, "as a practitioner, I have found Professor Ghemawat's CAGE framework to be the most directly applicable IB concept for measuring the cultural, administrative, geographic and economic 'distances' between countries in order to map out a go-to-market strategy based on the relative 'closeness' of other countries." His comment reminded me that all research is basically comparative-whether explicitly or implicitly.

Peter Buckley commented that international-business (IB) research privileges one dimension of variation — nationality — above others such as industry, region, and dimensionality (e.g., size). This is true whether we look at the firm, the manager, the owners or the location as the primary focus of interest.

He added that the approach Mark Casson and he have taken "in our 1976 book The Future of the Multinational Enterprise is to see the national firm as a special case of the multinational firm - not the other way around. This chimes well with current approaches, not least with the notion that many firms are 'born global.' For instance, we stated that: 'The location strategy of a firm with integrated production, marketing and R\&D has a characteristic form attributable to the fact that knowledge is a public good within the firm, and its transmission costs are normally low. This means that the exploitation of proprietary knowledge is logically an international operation. For similar reasons, the search for knowledge in a particular field is also an international operation' (p. 35)."

To be sure, strong regulation at the industry level may constrain national firms from becoming MNEs but "the link between the internalisation of markets and the existence of MNEs is very simple: an MNE is created wherever markets are internalised across national boundaries (p. 45)."
This fact has a strong implication for IB research: "The characteristics of MNEs are thus attributable not to their multinationality per se but to the factors which govern internalisation in the industries in which they operate (p. 35).

In summary, MNEs are the general case and national firms are a special case where contextual conditions prevent the internalisation of markets across national frontiers. Therefore, the national dimension is an important source of regularities coinciding with national boundaries but it is not the only source of variation."Well said, Professor Buckley!

Lorraine Eden agreed that, "for research to be "truly international," both the dependent variable and independent variable need to be "international" defined as "inter-national" where "inter" means "between or among" countries. For instance, the external motivations affecting transfer pricing comes close to fitting this description of a "truly IB" phenomenon since, by far, the bulk of transactions and interesting issues involved in transfer pricing occur across national borders. However, your article on what constitutes international research reminded me of three others.

The first was Sundaram and Black's article on "The Environment and Internal Organization of Multinational Enterprises" (1992) where they defined the key features of the IB environment as being "multiple sources of external authority" and "multiple denominations of international value". In fact, I think that only the first feature is key, what with multiple government entities at the national or international level setting different rules that affect the multinational firm.

The second was John Dunning's original three-fold way to think of MNE advantages: (1) those advantages that one firm has over another firm in the same place (Ricardian rents); (2) those advantages that arise from the firm having multiple plants and/or market in different locations inside the same country (multi-plant or multi-market firm), and (3) those advantages that arise from the firm having multiple plants and/ or markets in different countries. Dunning argued that the only true advantages that multinationals have over other firms or organizations are those that arise from the third set - that is, from being able to take advantage, whether through arbitrage, leverage, integration or coordination of having access to multiple plant locations and multiple 
markets in different countries. The truly IB phenomena are those which give rise to multinationality's advantages."

The third piece is the article that Professor Eden, Dan Li and Li Dai (2010) wrote: "International Business, International Management, International Strategy: What's in a Name?" "In that piece, we compared the fields of international business, international management and international strategy in order to identify the critical importance of truly international phenomena in each one of these three fields."

As you can tell, the issue of what constitutes "truly international"research is an old issue that remains young forever!

\section{References}

Buckley, P.J., \& Casson, M.C. 1976. The future of the multinational enterprise. New York: Holmes \& Meier Publishers, Inc.

Eden, L. E., Li, D., \& Dai, L. 2010. International business, international management, international strategy: What's in a name?" International Studies of Management \& Organization, 40(4): 54-68.

Sundaram, A. K., \& Black, J. S. 1992. The environment and internal organization of multinational enterprises. Academy of Management Review, 17(4): 729-757.

Jean Boddewyn (Jean.Boddewyn@Baruch.cuny.edu) spent more than 40 years reading, teaching and researching "international business." He retired in 2006 as Emeritus Professor from Baruch College (CUNY) after teaching at NYU (1964-1973) and the University of Portland (OR) (1957-1964) while his Ph.D. was obtained at the University of Washington (WA) in 1964. He served as AIB President (1992-1994), Dean of the AIB Fellows (2005-2008), Chair of the International Management Division of the Academy of Management (1975-1976) and Founding Editor of International Studies of Management \& Organization (1971-2006). 